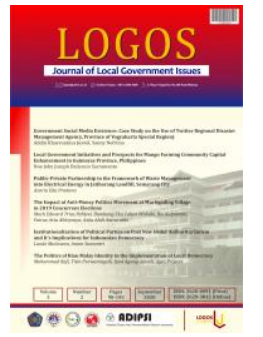

Volume 4 (2) (2021). 136-154

Journal of Local Government Issues

LOGOS

(LOGOS)

ISSN: 2620-8091 print | 2620-3812 online

Journal Homepage : http://ejournal.umm.ac.id/index.php/LOGOS/index

\title{
The Role of the Indonesian Tobacco Farmers Association in Mobilizing Resistance to Tobacco Regulation in Temanggung Regency
}

\author{
Bagas Makhrus Wicaksono', David Efendi2 ${ }^{*}$, Alam Mahadika ${ }^{3}$ \\ 1,2,3 Department of Government Studies, Faculty of Social and Political Sciences, Universitas \\ Muhammadiyah Yogyakarta \\ Jl. Brawijaya Kasihan Bantul, Yogyakarta, Indonesia, 55183 \\ *Corresponding author: defendi@umy.ac.id
}

\begin{abstract}
This research focuses on the mobilization of the role carried out by the movement Indonesian Tobacco Farmers Association (APTI) of Temanggung Regency is to thwart the implementation of NonSmoking Areas (KTR) that will be applied in Temanggung. They pressing for Regulation of the Ministry of Agriculture Republic Indonesia Number 23 of 2019 About Technical Recommendations For Tobacco Imports to be realized immediately, the allocation of Tobacco Excise Revenue Sharing Fund (DBH- CHT) returning to farmers is raised, and the rejection of the increase in retail selling price and excise that rises significantly. By using social movement theory with qualitative descriptive methods where primary data is obtained in direct interviews with respondents and sources who have valid and relevant information to find out the actual problems experienced by tobacco farmers, especially in Temanggung Regency. Then the authors use secondary data to strengthen the validity of the data obtained by the researcher. The results of this study illustrate that tobacco control regulations are not entirely for public health but are used as a pretext in the nicotine market share. So far, APTI has carried out various ways and strategies so that national-scale regulations can be changed or removed. In addition to tobacco control regulations, there are also classes of tobacco farmers in Temanggung to give birth to local capitalization and make the tobacco trade chain longer.
\end{abstract}

Article Info :

\section{INTRODUCTION}

The initial goal that in the establishment of Indonesian Tobacco Farmers Association is as a reaction to government regulations that are considered burdensome for tobacco farmers in Temanggung by limiting Tar and nicotine levels in cigarettes is considered irrelevant if applied in Temanggung given the very high levels of Tar and

Please cite this article as: Mahadika, A. ., Wicaksono, B. M. ., \& Efendi, D. . (2021). The Role of the Indonesian Tobacco Farmers Association in Mobilizing Resistance to Tobacco Regulation in Temanggung Regency.Journal of Local Government Issues (LOGOS), 4(2), 136-154. https://doi.org/10.22219/logos.v4i2.17894 
nicotine tobacco Temanggung and with government policies that are more in favor of foreigner (Nurwiyati \& Herawati, 2017). With the establishment of the Indonesian Tobacco Farmers Association as a social movement of tobacco farmers to oppose policies that are not in accordance with tobacco farmers.

Indonesia is an agrarian country most of its population is eyed in agriculture. In terms of geography, Indonesia is located in a tropical region that has high rainfall so that many types of plants can live, so ecologically provides benefits for Indonesian flora, namely plants can thrive (Hardanis \& Poerwono, 2013). Not only known as an agrarian country, Indonesia is also the sixth largest tobacco producing country in the world with a production of 164,851 tons / year (Nurwiyati \& Herawati, 2017). Tobacco yields in Indonesia can account for $2.67 \%$ of tobacco leaves from the global supply. Tobacco as a strategic commodity is a fact that this commodity is still one of the country's financial sources. Indonesia's total tobacco farm area reached 204,562 hectares in 2019 (Perkebunan).

Tobacco is concentrated in three provinces, including East Java, Central Java and West Nusa Tenggara. With land area in East Java from 2016 to 2019 is increasing. In 2016 the area of agriculture was 64,143 ha, in 2017 it rose to 100.75 ha and in 2018 to 105,492 ha until 2019 to 105,595 ha. In Central Java from 2016 to 2019 there was an increase and decrease in 2016 the area of tobacco farming area of 42,794 ha, in 2017 increased to 45,085 ha, in 2018 decreased to 42,362 until finally in 2019 rose to 42,700 ha. In West Nusa Tenggara Province experienced an increase and decrease in 2016 with an area of 27,178 ha, in 2017 there was an increase of 33,793, until 2018 it decreased to 32,854 ha, and 2019 increased to 33,811 ha (Perkebunan). The area of tobacco plants in Temanggung Regency, Central Java, decreased by about 4,600 hectares in 2020 compared to last year. The decline of the site is related to the Covid-19 pandemic period, and finally, tobacco farmers - also prioritize food crops (Maskur, 2020).

Table 1. Area of Tobacco Agriculture and Tobacco Production 2015 - 2019

\begin{tabular}{|c|c|c|c|c|c|c|c|c|c|c|c|}
\hline \multirow[t]{2}{*}{ No } & \multirow{2}{*}{$\begin{array}{c}\text { Provinc } \\
\text { e }\end{array}$} & \multicolumn{6}{|c|}{ Area Tobacco Farming } & \multicolumn{4}{|c|}{ ProductionTobacco } \\
\hline & & 2015 & 2016 & 2017 & 2018 & 2019 & 2015 & 2016 & 2017 & 2018 & 2019 \\
\hline 1 & $\begin{array}{c}\text { Eeast } \\
\text { Java }\end{array}$ & $\begin{array}{c}108.54 \\
2\end{array}$ & $\begin{array}{c}64.14 \\
3\end{array}$ & $\begin{array}{c}100.75 \\
0\end{array}$ & $\begin{array}{c}105.42 \\
9\end{array}$ & $\begin{array}{c}105.59 \\
5\end{array}$ & $\begin{array}{c}99.74 \\
3\end{array}$ & $\begin{array}{c}42.19 \\
1\end{array}$ & $\begin{array}{c}79.44 \\
2\end{array}$ & $\begin{array}{c}84.01 \\
5\end{array}$ & $\begin{array}{c}85.05 \\
3\end{array}$ \\
\hline 2 & $\begin{array}{c}\text { Central } \\
\text { Java }\end{array}$ & 52.470 & $\begin{array}{c}42.79 \\
4\end{array}$ & 45.085 & 42.362 & 42.700 & $\begin{array}{c}40.56 \\
4\end{array}$ & $\begin{array}{c}27.92 \\
4\end{array}$ & $\begin{array}{c}38.34 \\
1\end{array}$ & $\begin{array}{c}34.28 \\
3\end{array}$ & $\begin{array}{c}34.00 \\
6\end{array}$ \\
\hline 3 & $\begin{array}{c}\text { West } \\
\text { Nusa } \\
\text { Tenggar } \\
\begin{array}{c}\text { a } \\
\text { To }\end{array}\end{array}$ & 23.760 & $\begin{array}{c}27.17 \\
8\end{array}$ & 33.793 & 32.854 & 33.811 & $\begin{array}{c}34.44 \\
9\end{array}$ & $\begin{array}{c}39.59 \\
0\end{array}$ & $\begin{array}{c}43.97 \\
1\end{array}$ & $\begin{array}{c}43.77 \\
8\end{array}$ & $\begin{array}{c}44.94 \\
3\end{array}$ \\
\hline
\end{tabular}

Source: Directorate General of Plantations, Ministry Of Agriculture Republik Indonesia, 2020

But in fact, although Indonesia is blessed with abundant natural resources farmers still complain about low levels of welfare, even though the agricultural sector is a sector that has a strategic role in regional to national economic development (Bonde,

137| Journal of Local Government Issues (LOGOS), 4 (2), September 2021, pp 136154

ISSN : 2620-8091 print | 2620-3812 online 
2019). Especially for farmers in Temanggung Regency which is one of the tobacco producing areas in Central Java Province. Temanggung Regency and tobacco as a unit that cannot be separated, most of temanggung people depend on tobacco commodities so that they can meet their needs (Prasetiyo, Djajadi, \& Sudarto, 2017).

The Government of Temanggung Regency, Central Java, in 2020 stated that the planting mass in 2020 decreased to 2000 hectares compared to 2019. In 2019 it reached about 18,000 hectares, and in 2020 the land area of tobacco plants was only about 16,000 - a decrease in tobacco plants' land area related to pandemic Covid-19 (Suyitno, 2020). Especially in tobacco farmers today expect significant purchases from large-scale companies. This is due to the impact of the Covid-19 pandemic, so that previously dilatuh tobacco crop soil from Temanggung also decreased.

The production of tobacco plantations is one of the sources of income in Temanggung, namely Srinthil tobacco is the best quality tobacco that is a native Indonesian product produced by the Temanggung area. Even these types get a Certificate of Geographical Indication from the Ministry of Law and Human Rights. Extensive data on the harvest and production of tobacco crops in Temanggung Regency based on data from the Food Security, Agriculture and Fisheries Office of Temanggung Regency.

Table 2. Area of Harvest, Production and Productivity of Temanggung Regency 2016 2018

\begin{tabular}{|c|c|c|c|c|c|c|c|}
\hline \multirow{3}{*}{ No } & \multirow{3}{*}{ District } & & \multirow[b]{2}{*}{2018} \\
\hline & & 2016 & 2017 & 2018 & 2016 & 2017 & \\
\hline & & Large Ha & Large Ha & Large Ha & $\begin{array}{l}\text { Productio } \\
\text { n Kg }\end{array}$ & $\begin{array}{l}\text { Productio } \\
\text { n Kg }\end{array}$ & $\begin{array}{l}\text { Productio } \\
\text { n Kg }\end{array}$ \\
\hline 1 & Ngadirejo & $2.404,45$ & $2.214,00$ & $2.235,00$ & $1.382,51$ & 1.553 .960 & 1.629 .250 \\
\hline 2 & Kandangan & 302,58 & 67,50 & 156,00 & 169,18 & 40.500 & 9.360 \\
\hline 3 & Parakan & $1.190,35$ & 843,00 & $1.388,00$ & 707,03 & 444.810 & 882.700 \\
\hline 4 & Kledung & $2.132,75$ & $2.090,00$ & $2.060,00$ & $1.246,53$ & 1.781 .045 & 1.465 .300 \\
\hline 5 & Kaloran & 86,50 & 198,40 & 68,00 & 58,71 & 79.360 & 34.000 \\
\hline 6 & Gemawang & 7,60 & 17,00 & 15,00 & 4,24 & 8.651 & 808 \\
\hline 7 & Tlogomulyo & $1.834,45$ & $1.864,00$ & $1.143,00$ & $1.052,83$ & 1.089 .944 & 532.200 \\
\hline 8 & Wonoboyo & $1.002,25$ & 455,00 & 901,00 & 570,98 & 395.600 & 640.370 \\
\hline 9 & Kranggan & 701,30 & 10,00 & 26,00 & 39,68 & 3.500 & 11.700 \\
\hline 10 & Tretep & $1.069,70$ & 973,00 & $1.231,00$ & 609,41 & - & 861.700 \\
\hline 11 & Bulu & $2.198,80$ & $2.128,50$ & $2.039,00$ & $1.333,90$ & 1.392 .039 & 1.040 .000 \\
\hline 12 & Jumo & 757,15 & 624,00 & 732,00 & 435,35 & 427.710 & 353.000 \\
\hline 13 & Bansari & $1.314,80$ & $1.261,79$ & $1.346,00$ & 774,01 & 929.416 & 116.600 \\
\hline 14 & Tembarak & $1.399,35$ & 861,40 & $1.028,00$ & 804,60 & 516.840 & 353.000 \\
\hline 15 & Temanggung & 254,60 & 268,00 & 471,00 & 147,73 & 264.248 & 359.800 \\
\hline 16 & Candiroto & 921,50 & 925,00 & $1.010,00$ & 539,37 & 680.200 & 770.900 \\
\hline 17 & Selopampang & 637,45 & 466,00 & 445,00 & 363,16 & 297.050 & 233.180 \\
\hline 18 & Kedu & 665,00 & 792,20 & 422,00 & 382,36 & - & 220.000 \\
\hline 19 & Pringsurat & - & - & - & - & - & - \\
\hline \multirow[t]{2}{*}{20} & Bejen & - & - & - & - & - & - \\
\hline & Amount & $18.879,08$ & $\begin{array}{l}16058,7 \\
9\end{array}$ & $\begin{array}{l}16716,0 \\
0\end{array}$ & $10.611,58$ & 9.904 .873 & 9.513 .868 \\
\hline
\end{tabular}

Source: Food Security, Agriculture and Fisheries Office of Temanggung Regency, 2019

138| Journal of Local Government Issues (LOGOS), 4 (2), September 2021, pp 136154

ISSN : 2620-8091 print | 2620-3812 online 
The importance of the law on trade is an important factor in the welfare of tobacco farmers themselves so that the role of the government contributes to it. One of the problems related to government policy is the passed Government Regulations (PP) Number 109 of 2012 on The Safeguarding of Products containing addictive substances in the form of tobacco for Health (Peraturan, 2012). This regulation states that tobacco becomes opium (an addictive substance) harmful to health. So it is necessary to test the content of Nicotine and Tar every variant produced, so that the cost of cigarettes narrows the wiggle room of advertising marketing and sponsorship. This is seen by farmers as more in the tendency to side with the government against foreigners. Protest movements are carried out to criticize and give opinions on policies that threaten the welfare of tobacco farmers (Sunaryo, 2013).

Protests are part of the democratic process when people mobilize collective resistance against a policy that is considered detrimental (Munck, 2015) (Jolley \& Steinfeld, 2019). This collectivity occurs because of the similarity of vision and values or situations experienced (Neira, 2018) in some ways related to the solidity of ethnicity (Anderson, 2019), culture (Juris, 2015) and leads to civic engagement (Lejano, Chui, Lam, \& Wong, 2018). Several movement studies show how protests are conducted through social media (Hill, Canniford, \& Millward, 2018) like in Hong Kong 2014 (Jacobs, 2016), anti-Berlusconi protests in Italy (Coretti \& Pica, 2015), in Delhi through the Pinjra Tod (Break the Cages) movement (Lochan, 2019) and three major cities in Morocco: Rabat, Casablanca, and Meknes to seek to limit the power of a kingdom rife with scandals of corruption and nepotism by activists (Laouni, 2020). Other studies have also shown that the protest movement is motivated by many factors. In Poland in 2012-2019, small farmers protested because agricultural policies made by the government were considered detrimental to farmers (Bilewicz, 2020). In 1965-1969 protests occurred at the University of Pennsylvania due to the Vietnam war policy by the United States, which was very detrimental to the interests of humanity (Asregadoo, 2017). Still in the United States, protest movements also continue to occur due to repeated incidents of racism in the United States (Hoffman, Granger Jr, Vallejos, \& Moats, 2016). In the Egyptian revolution, the similarity of the situation due to the government's inability to lead was able to fuse the identities of different communities to carry out a protest movement jointly (Baker, 2016).

Based on the above description, the existence of the Indonesian Tobacco Farmers Association (APTI) of Temanggung Regency aims as a messenger / liaison between farmers and the government. APTI is part of the process towards a better and more advanced state, every empowerment program that APTI undertakes is an effort to deliver farmers to a better and prosperous state. This research will focus on the role of the strategy used by the Indonesian Tobacco Farmers Association (APTI) of Temanggung Regency, with resistance to the rights of farmers threatened by tobacco control regulations that do not favor farmers and harm national to local tobacco farmers. So far APTI Temanggung Regency has carried out various actions ranging from auditioning with stakeholders, maximizing existing political opportunities, to mass action carried out so that the Draft Law can be immediately passed into the Constitution Law, so that the Minister of Finance Regulation 152 of 2019 can be revised again or

139| Journal of Local Government Issues (LOGOS), 4 (2), September 2021, pp 136154

ISSN : 2620-8091 print | 2620-3812 online 
revoked and the main rejection of non-smoking areas in Temanggung Regency where it is contained in Government Regulation 109 of 2012 (Peraturan, 2012).

On January 9, 2018 hundreds of tobacco farmers from the Indonesian Tobacco Farmers Association (APTI) from various regions in Central Java, by deploying hundreds of tobacco farmers held a demonstration in front of the central Java Governor's office in Semarang (Huda, 2017). Furthermore, on October 24, 2019 dozens of tobacco farmers on behalf of the Indonesian Tobacco Farmers Association (APTI) of Temanggung Regency took action to Jakarta, dozens of farmers expressed objections to the increase in excise which is based on the Regulation of the Minister of Finance 2019 (Ramli, 2019). After that November 11, 2019 the Indonesian Tobacco Farmers Association (APTI) of Temanggung Regency and tobacco farmers from 10 provinces in Indonesia in Indonesia held a National Leadership Meeting on the increase in excise and the impact of the Minister of Finance Regulation in 2019, the meeting was a statement of aspiration from the farmers' coalition regarding unrest over government regulations (Rizqi, 2019).

Based on the background that has been described above, researchers formulated the researcher's question as follows How to mobilize the Indonesian Tobacco Farmers Association (APTI) of Temanggung Regency in fighting for the rights of tobacco farmers. As well as the purpose of this study to find out the role and strategy carried out by the Indonesian Tobacco Farmers Association (APTI) of Temanggung Regency in protecting and fighting for the interests of farmers and the impact that occurred based on Government Regulation Number 109 of 2012, especially in article 49, namely the regional government of Temanggung Regency will implement a Non-Smoking Area, Tobacco Import Trends, Regulation of the Minister of Finance 22 of 2017 and Regulation of the Minister of Finance 152 of 2019.

In Indonesia, several studies have looked the public protest movement. (Iryana, 2016) see how the Indramayu farmers protested against the Japanese compulsion to give up their rice. (Cima, 2015) In his research in Aesesa Subdistrict, Nagekeo Regency, NTT, he photographed community protests over the construction of the Mbay Kiri irrigation channel through demonstrations because it was considered detrimental to customary land. (Erman, 2017), His study showed the formation of a collective of Chinese workers united by ethnic sentiments to protest the exploitation they experienced at the Tin Mine in Bangka-Belitung (1920-1950). (Hartutik \& Sukirno, 2018) shows that the release of land reform through The Basic Agrarian Law (UUPA) of 1960 was opposed by the Klaten farmers through continuous protests because it was considered to have robbed them of their land ownership. Other studies are also conducted (Muhammad, 2013) which describes the occurrence of public protests (demonstrations) to the Regional People's Representative Council (DPRD) due to the village head election (Pilakdes) in the village of Kalitan Klaten, Central Java in 1998 was considered fraudulent. The elected Village Head, Rajimin, is considered to have done much manipulation.

Furthermore (Kasanti \& Adnan, 2019), stated that Juwana fishers carried out a protest movement because of prohibiting the use of cantrang, which was very detrimental to them. The protests are tiered starting from the regional level, central protests, complaints to institutions, and meetings with the Minister and the President.

140| Journal of Local Government Issues (LOGOS), 4 (2), September 2021, pp 136154

ISSN : 2620-8091 print | 2620-3812 online 
(Iryana, 2017) show that Social Protest of Parean Girang Community, Indramayu against the Relocation of Pig Farms (1995-1996). (Fernyawan, 2021) linking the protests of farmers around the Serayu irrigation area due to the lack of communication and socialization carried out by the government. The last (Hendarto, 2021) see that tempe farmers protest because of the plan to import soybeans through media analysis. Different with previous research, this article offers a different focus because it looks at how the protest mobilization carried out by the Farmers' Association in Temanggung on cigarette regulation, something that has never been done by previous researchers.

\section{METHOD}

This qualitative research uses data collection techniques by conducting observations, review of official and post-conflict documents and media coverage, Literature review, and in-depth interviews with several primary actor sources, namely the Indonesian Tobacco Farmers Association (APTI) of Temananggung Regency and critical informants in Temanggung as a research area located in Temanggung, Central Java. The various techniques selected are intended to obtain valid, factual, and quality data. This qualitative research is very appropriate to look at phenomena in welfare development efforts in the border region and the qualitative research power formulated (Denzin \& Lincoln, 2011).

That is, the fulfillment of diverse information needs is the characteristic of qualitative research. According to (Creswell \& Creswell, 2017), it is a requirement where researchers must hold fast to aspects called "complex and holistic," both in the data and in the stages of analysis. This is also the same age as qualitative research characteristics: naturalistic, descriptive data, focus in process, inductive, and makingmeaning.

In this research, the authors follows Lincoln and Gube (2008), data collected were validated using four quality criteria: credibility, transferability, dependability, and confirmation (Emzir, 2013). Credibility is related to how data are trusted; transferability shows a diverse context; dependability is interpreted as a repetition of the same situation; finally, confirmability means that the researcher's perspective is not uniform. The four validation tools mentioned above are different from the norms in quantitative data validation, which usually includes internal, external, reliability, and objectivity validity tests. This study will use Miles and Huberman models through several procedures as follows: (1) Data coding/reduction; (2) thematization; (3) determining the storyline; (4) developing the storyline and theorizing; (5) analysis by linking themes with available theoretical theories and looking for relationships with other themes; (6) drawing conclusions.

\section{RESULTS AND DISCUSSION}

APTI Temanggung was established to protect and accommodate the interests and needs of tobacco farmers to maintain their existence in their economic fulfilment. The Solidarity of people in APTI Temanggung are people who seek to care about protecting tobacco farmers. The politics of resistance maintained by APTI, namely the APTI Temanggung program, is carried out to develop tobacco farmers and show the government about the existence of justice for farmers and political resistance APTI

141| Journal of Local Government Issues (LOGOS), 4 (2), September 2021, pp 136154

ISSN : 2620-8091 print | 2620-3812 online 
Temanggung expressed criticism by protesting as a form of reaction of tobacco farmers to reject a form of tobacco farmers. Government regulations do not accommodate the interests of farmers and will kill tobacco farmers. For a deeper discussion of this research, APTI Temanggung focuses on struggle government regulation (Nurwiyati \& Herawati, 2017).

\section{Government Regulation is the Root of Resistance.}

The background to the resistance of tobacco farmers emerged in 1999, namely about the safety of cigarettes for Health which is said to contain opium (Addictive Substances). The emergence of tobacco regulation in Indonesia in 1999 with the Government Regulation Number 81 of 1999, which was signed by President Habibie. In the regulation there is a crucial article that regulates the limits of Tar and nicotine, it is the emergence of the movement of tobacco farmers in Indonesia.

Quoting what was conveyed by the Regional Leadership Council of Indonesian Tobacco Farmers:

"At that time there was no Indonesian Tobacco Farmers Association (APTI), but some farmers understood that the articles in Government Regulation number 81 were a threat to farmers. When the farmer reads and observes both in print and from online media makes them more convinced that it is very dangerous because it is regulated regarding standardization it is very inversely proportional to what is or is contained in local Indonesian tobacco" (Interview, 2019).

Context of global trade, modern capitalism has two issues that they use to dominate the global market, namely the health market and standardization. The standardization that they conform to their standardization and does not include the labor of tobacco farmers. In article 4 of the Government Regulation 1999 the second part of nicotine and Tar levels states, the level of nicotine and Tar content in cigarettes in the territory of Indonesia should not exceed the level of nicotine content of $1.5 \mathrm{mg}$ and Tar content of $20 \mathrm{mg}$, after which the level of nicotine and Tar content as referred to in paragraph (1) based on the procedures of the applicable examination method (P. R. Indonesia, 2007).

Nicotine $1.5 \mathrm{mg}$ and Tar $20 \mathrm{mg}$ clearly regulates that that can supply raw materials is tobacco from them (Imported Tobacco) Some other farmers form the SindoroSumbing Tobacco Farmers Association (PPTSS) of Temanggung Regency and Wonosobo Regency. The background to the formation of PPTS is to advocate for government regulations that exist at that time.

Quoting what was conveyed by the Regional Leadership Council of Indonesian Tobacco Farmers:

"Thegovernment always says "Show the article prohibiting farmers from growing tobacco and pointing out the article that prohibits the production of cigarettes" in Government Regulation 81 of 1999 is indeed no such ban. There are PPTSS representatives criticizing the government that this standardization is dangerous and has a long-term impact. And this is true that some capitalintensive industries follow the standardization of these regulations with product innovation, and the result appears white cigarettes (Mild) which only have local content below 20\%"(Interview, 2019).

142| Journal of Local Government Issues (LOGOS), 4 (2), September 2021, pp 136154

ISSN : 2620-8091 print | 2620-3812 online 
The market of white cigarette sales (Mild) in 2000 was only 7\%, with the global capitalism movement designing existing regulations in Indonesia making farmers often unaware that the regulation supported the global capitalism movement. Articles such as The Non-Smoking Area make this white cigarette (Mild) percentage is quite up. In 2003 tobacco imports in Indonesia (Virginia tobacco) were about 28,000 tons, in 2010 it rose to 90,000 tons and by 2012 it was already at 150,000 tons (Keuangan, 2019).

The emergence of Government Regulation Number 109 of 2012 on The Safeguarding of Substances Containing Addictive Substances with tobacco products for Health shows the government does not side with tobacco farmers. Whereas the birth of PP 109 in 2012 is a derivative of Article 116 of the Law of the Republic of Indonesia Number 36 of 2009 on Health (R. Indonesia, 2009). Article 116 Health is related to the safety of substances containing addictive substances. Article 166 has provided its own arrangements whose scope is regulated in the Law. Article in it there is a crucial rule, Government Regulation Number 109 of 2012 is not a rule that protects health, but it has led to interests.

The emergence of an increase in tobacco imports that occurs every year is the impact of the unrealized Regulation of the Minister of Agriculture (Permentan) Number 23 of 2019 concerning Technical Recommendations for Tobacco Imports. Article 15 of Law Number 19 of 2013 concerning the Protection and Empowerment of Farmers, in the Ministerial Regulation regulates the procedure for importing tobacco. There are several articles that stipulate that there are 20 articles in it and the article that regulates the terms of import is contained in article 5 paragraph 1 "Tobacco importers are obliged to absorb domestic tobacco as raw material for kretek cigarettes and white cigarettes", in article 5 paragraph 3 "To prove the absorption capacity of Tobacco, Tobacco importers submit evidence of farmers' tobacco absorption of at least two times the amount requested as raw material for the tobacco industry", furthermore in Article 9 paragraph $1 \mathrm{a}$ "statement of import plans in accordance with real needs". industry and a statement that it will not trade or use imported tobacco to other parties, for P-fire holders",

If article 5 paragraphs 1 and 2, and article 9 paragraph 1a means that companies that already have NIB (Master Number) if they want to apply for tobacco imports must make a report on local absorption with a ratio of twice the needs you want to import, for example, if you want to import 50 tons of food the company must buy 100 tons of local tobacco, And the company must commit that the tobacco imports are actually used for the needs of the company, not for re-buying. This regulation is considered fair by farmers so it is very hopeful that the realization of request will soon be realized. Given the trend of tobacco imports, the percentage of tobacco increases every year, it can be seen on the graph:

Chart 1. Tobacco Import Increase in 2010-2018



Source: Central Bureau of Statistics (BPS) Indonesia, 2019

143| Journal of Local Government Issues (LOGOS), 4 (2), September 2021, pp 136154

ISSN : 2620-8091 print | 2620-3812 online 
From the chart 1 in 2011 the increase in imports in Indonesia reached 38\% from 2010 and in 2012 rose significantly to 52\%, although the next three years decreased but from 2016 to 2018 the percentage increase rose to $30 \%$. If this is allowed to happen and the government does not take decisive steps against the control of tobacco imports, of which imported tobacco is the main raw material of white cigarettes (Mild) the future impact is monopolistic dominance put forward by Andre Gunder Frank (1970) a dependency theory figure who argues that the relationship of dependence of the core state with the periphery state is characterized by monopolistic and extractive properties (Zaini, 2014).

\section{Tobacco Trading From Farmers To Cigarette Factories in Temanggung Regency}

In the process of determining tobacco prices and tobacco quality in Temanggung Regency, a meeting was held between cigarette factories, DPRD and farmers and village device work units (SKPD). Quoting one of the tobacco farmers in Temanggung:

"Theapplicable grade in Temanggung is with the letters A, B, C, D, E, F, G, H. Grade A, B, C, D for tobacco Grade is the selling value of tobacco based on tobacco quality.The applicable grades in Temanggung are with the letters $\mathrm{A}, \mathrm{B}, \mathrm{C}, \mathrm{D}, \mathrm{E}, \mathrm{F}$, G, H. Grade A, B, C, D for rice field tobacco and Grade E, F, G, H for legal tobacco. The price per grade ranges from Rp. 20,000 - Rp. 25,000 and each grade has a difference of Rp. 22,500 in 2019 (In Gudang Garam). The process of determining the price of tobacco agricultural products, namely the factory mentions the estimated price of tobacco based on the cost of planting to the production of tobacco agricultural products by farmers. Farmers, middlemen, DPRD, have discussions about profits and losses about the estimated prices provided by the factory. If the price given by the factory is considered a loss, the three parties request that the factory increase the estimated price. In the process of pricing occurs the process of bargaining to determine the grade. In this case APTI acts as a mediation between farmers and the government. APTI provides details of farmers' Break Event Point funds to the government of either regents or governors who are used as guidelines in pressuring manufacturers so that the purchase price of tobacco is at least above the farmer's BEP." (Interview, 2019).

In this discussion from several large industries that accommodate farmers' crops, namely tobacco, researchers refer to one cigarette industry in Temangung Regency that almost all absorption receives local tobacco, the industry is The Salt Warehouse. The industry makes branches in Temanggung Regency nothing but to be closer to the raw materials, namely Tobacco produced by farmers Temanggung tobacco and surrounding areas, because as a reference for good quality tobacco is in the region of 5 Mountains, namely Mount Prau, Mount Sindoro, Mount Sumbing, Mount Merbabu and Mount Merapi, and it is no longer an open secret that tobacco in Temanggung Regency is a prima donna tobacco (especially Srintil) so there are many industries. cigarettes that open branches in Temanggung Regency.

According to the right-hander Grader Bah Yen in tobacco trading in The Salt Warehouse as follows:

"If the tobacco has entered the Grader then sent to the warehouse but passes through a suitable handyman, the task of the suitable handyman is to match the

144| Journal of Local Government Issues (LOGOS), 4 (2), September 2021, pp 136154

ISSN : 2620-8091 print | 2620-3812 online 
pinpel carried by the middleman / basket taken from inside the tobacco faucet in accordance with the series, the name of the middleman who has the KTA farmer commission to basket) and Grade in the example and the contents of the faucet, and if it fits between the slingshot and tobacco in the faucet means entering if it is not suitable means returned to the middleman / basket. After that enter the press machine, in this stage is still in the process of checking that the tobacco that will be put into the machine in good condition means there is no problem but if the tobacco is damaged it will automatically return to the middleman / basket. But Gudang Garam had paid at the beginning by the time the tobacco faucet passed through the suitable handyman. Because the factory does not want to take risks or complaints after entering the Grader. In one tobacco faucet with an example of a weight of $50 \mathrm{~kg}$ cut with a faucet of about 5-6 kg, cut with a banana $2-3 \mathrm{~kg}$ so that the clean tobacco becomes $41-43 \mathrm{~kg}$, this is the benchmark price in terms of grade tobacco. If the real basket usually does an agreement from the beginning with farmers, namely the number range of Rp.2,500 to Rp.5,000 per kg because the tobacco is brought under the name of a basket that has a KTA (farmer commission to basket) but back again, the basket is cruel no, if cruel it could have taken a cut of Rp.15,000 per $\mathrm{kg}$, it could even be more"(Interview, 2020).

It can be concluded that the process of selling tobacco farmers' products that go into warehouses - warehouses that are produced by 5 graders. However, there is a long chain in the chain of commerce where small tobacco farmers can rarely sell to baskets but there are still some intermediate lines. Every year warehouses owned by Gudang Garam always buy more than the tonnage needed warehouses for the Temanggung area. This is the initial picture of the trading system in Temangung regency, and in the next section the researcher will try to explain from the data and interviews conducted by researchers.

\section{Tobacco Trading Chain in Temanggung Regency}

In the tobacco trade (Table 3), Grader has an important role in assessing the tobacco of farmers who enter the cigarette industry. The quality of tobacco is determined by the Grader who assesses tobacco based on the aroma, shape and taste of tobacco that will be sold to cigarette companies. Based on the subjective assessment of the grader, the price of tobacco is set in accordance with the grade that has been determined in Temanggung Regency

Table 3. Tobacco Trading Chain in Temanggung

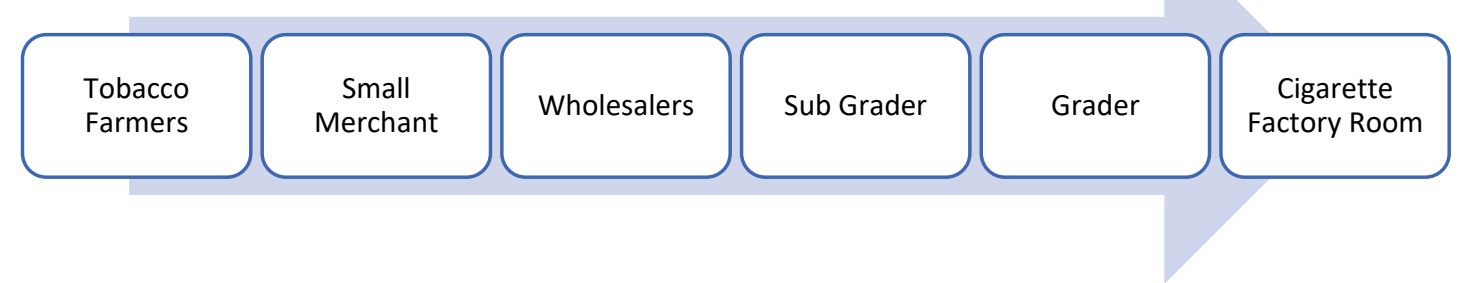

Source: Researcher, 2019

145| Journal of Local Government Issues (LOGOS), 4 (2), September 2021, pp 136154

ISSN : 2620-8091 print | 2620-3812 online 
Grader in Gudang Garam still has a familiar relationship with industry and descendants of Grader's parents who used to be also Grader because Grader himself must have sharp vision and smell to tobacco because this is very important in determining the quality and providing a price to the results of tobacco farmers and until now there is still no technology to replace Grader in determining the quality of tobacco objectively. Grader itself has a suitable handyman who is in the warehouse, his job is to match tobacco samples with faucets containing tobacco that on average each basket contains $45-60 \mathrm{~kg}$ of tobacco, which is brought middlemen / baskets (who have KTA) to the industry and of course have been assessed Grade and price by Grader. During this time Grader also has several baskets / middlemen who remain consistent in carrying tobacco faucets derived from leaves that have been banded by farmers, so that with a total of 500 KTA owners already have subscriptions selling to 5 Graders.

\section{Local Capitalization}

Researchers tried to conceptualize tobacco farmers into 3 classes of farmers, namely small farmers who have little production land, the second farmers who have little land but tobacco production is greater, the third is farmers who do not own land but have greater tobacco production compared to farmers who own land.

From the above concept to be a reference for researchers in unraveling the problem of farmers at the local level, it should be emphasized also in Temanggung Regency the type of tobacco produced by local farmers is not only two types, namely rice field tobacco and tegal tobacco, but there is Temanggungan tobacco, Temanggung tobacco is tobacco that is produced from tobacco that is not local friends, but tobacco produced by farmers who are still in the country and processed into similar tobacco even in the country. ampir is the same as the original tobacco of Temanggung Regency.

According to the National Leadership Council (DPN) APTI said:

"This local capitalist has actually been a culture from the past. Actually we do not forbid for them to seek sustenance but at the very least, Mr. Regent can play a role to be in conflict with the industry, so that there is a price between tobacco friends (garut, ban-yuwangi, east Java and so on), because Temanggung Regency which is the host should have a policy or advocate to the industry so that the date of its buyer when the Temanggung tobacco harvest is completed, the second difference in price is different from local (friends) and the third spent first from friends, after that only received from outside the Temanggung" So that there is a priority there, because it is legitimate because it is still from the pdoduktembakkau in the country, and another one, if non-mafia" (Interview, 2020).

As the researchers conceptualized in the previous section, the "family farming business" does not necessarily own land even though there is land, but the total tobacco production is greater than the land owned. These family farmers follow the standards given by cigarette factory warehouses according to the Grade in Temanggung Regency from color, texture to aroma. However, the tobacco is a mixture of some tobacco that is still national in scale, although there is a good side, which is to help other areas to be able to sell their crops in Temanggung Regency.

146| Journal of Local Government Issues (LOGOS), 4 (2), September 2021, pp 136154

ISSN : 2620-8091 print | 2620-3812 online 
As the researchers conceptualized in the previous section, the "family farming business" does not necessarily own land even though there is land, but the total tobacco production is greater than the land owned. These family farmers follow the standards given by cigarette factory warehouses according to the Grade in Temanggung Regency from color, texture to aroma. However, the tobacco is a mixture of some tobacco that is still national in scale, although there is a good side, which is to help other areas to be able to sell their crops in Temanggung Regency. One of the tobacco farmers in Legoksari Village which has an area of land owned by 3 (Ha) and planted with tobacco said:

"This family farming business is the worst to damage the price and quality of Temanggung local tobacco, For example in Jragan Region, where the majority as a "family farming business" tobacco there and APTI has never given a rebuke to them (family farming business), I think both APTI and Food Security, Agriculture and Fisheries Office (DINTAPANGAN) of Temanggung Regency should dare to rebuke this "family farming business". Because of the impact of small farmers here become eliminated, if the next 10 years if this "family farming business" is left then farmers who still use local tobacco will be eliminated, and the welfare of tobacco farmers will be far from farmers because of this imported tobacco. During this time farmers in Legoksari ranging from picking leaves, the process of lengthening to become faucets takes 15 days, even though the average is only 5 faucets, but if done "family farming business" (Jragan Village) small players in a day can reach 30-40 faucets in one day" (Interview, 2020).

In addition to the problems of the above peasant classes, then at the time of sales in cigarette factory warehouses, most collectors, small traders, and large traders have not implemented a pay weight system, meaning not buying farmers' tobacco directly pay but waiting for payment from the cigarette factory warehouse. While the cigarette factory buys it by paying directly when tobacco enters the warehouse although in 2019 there is a Task Force on Trade stipulated through Regent's Decree Number 510/369 of 2019 dated August 28, 2019.

It aims as an effort by the district government to ensure that the process of selling tobacco crops can provide welfare for all parties, especially among farmers, traders and graders. With the function of controlling that agricultural business and tobacco trade from the level of farmers, traders and manufacturers, can run smoothly and mutually beneficial. The District Government expects that no party will be harmed in the business process of trade, as well as ensure economic justice at each level of the actors of the trade as tobacco farmers say.

"In my opinion, the tobacco group is a good goal but as a criticism is that some of its members do not understand about tobacco, about price control is good, but when it comes to the national context must have a legal umbrella, for just friends can not. Because in Indonesia we are more liberal than the country of origin liberal, Yana where all is left to the free market." (Interview, 2020).

Furthermore, according to APTI member and Chairman of TaniSidaMulya in Legoksari Village said:

"I think the Task Force is still in the formulation stage and has not reached the realized stage, although the task force has been formed at the end of 2019 but is 
still in the stage of collecting data and information. I understand very well and I really appreciate the policy of the Regent so as not to be rash in making rules there because the context of tobacco farmers there are many, ranging from mountain tobacco farmers, rice field tobacco farmers, moorish tobacco farmers and there are also actors of racism will be able to accommodate all there" (Interview, 2020).

From the above explanation about tobacco trading in Temanggung Regency, researchers concluded that in the process of selling farmers' products, namely tobacco that has only been absorbed by the cigarette industry is different from the production of other commodities and currently in Temanggung Regency has become a free market, where the tobacco is not only Temanggung local tobacco but there is also tobacco that is still on a National scale entered in the market. So it can not only be solved with the Task Force, but must involve all the elements in it.

\section{Indonesian Tobacco Farmers Association Containers Social Movement}

The Indonesian Tobacco Farmers Association of Temanggung Regency has a movement that on a National and Local scale is what occurs due to regulations in their own country that are not partial to tobacco farmers, the principal and elements of society depend on tobacco where the regulation of constitutional products must have a principle that accommodates the rights of all parties who will eventually be affected by the enactment of the regulation (Nurwiyati \& Herawati, 2017).

APTI Action Temanggung regency at some time ago precisely on Monday, December 2, 2019 in the courtyard of the Office of the Secretary of Temanggung Regency held a peaceful action voicing the aspirations of tobacco farmers, especially in temanggung regency involving more than 500 farmers and Laskar Kretek Temanggung Regency related to the Non-Smoking Area (KTR) in Temanggung Regency, in the action not only rejection of KTR but also objected to the contents of the revision of Government Regulations (PP) Number 109 years 2019 is currently under discussion. The action was carried out to welcome the visit of the team from the Coordinating Ministry for Human Development and Culture (Kemenko PMK) RI related to the implementation of Non-Smoking Areas (KTR) and the shelter of local government aspirations in the change of Government Regulation Number 109 of 2012. The action was carried out safely and orderly, its delivery by stretching the beams and loudspeakers and sitting together in front of the Office of The Temanggung Regency Setda so that aspirations could be conveyed and achieve the expected goals.

Quoting one of the representatives of the Indonesian Tobacco Farmers Association of Temanggung Regency:

"Some time ago we made a visit to the ministry of health in relation to the NonSmoking Area (KTR) to carry out a rejection and insist on the regents not to ratify KTR in friends, except in two places, namely in the Health Service and in the Education Office, but for other places we do not agree and we will try to smoke anywhere except in the twoagencies" (Interview, 2020).

The next movement by APTI Temanggung Regency is to conduct a peaceful action of 20 people to go to the State Palace, In the action was carried out by unfurling a

148| Journal of Local Government Issues (LOGOS), 4 (2), September 2021, pp 136154

ISSN : 2620-8091 print | 2620-3812 online 
message containing protest attitudes, and voicing the screams of tobacco farmers with pmk 152 in 2019, it has been explained earlier that the increase in excise duty and HJE (retail selling price) which rose almost $22 \%$ and was too high will have a direct impact on the sustainability and welfare of tobacco farmers, can even kill the tobacco sector. Heat reminded in practice so far tobacco can only be accommodated cigarette manufacturers and the government also does not have technology that can afford to buy farmers' tobacco. Actually it is legal to raise taxes and HJE, but the regulation must also look at the benefits and impacts because with prices rising significantly without seeing the economic economy of Indonesia the impact is to kill the tobacco sector and not compared to foreign countries whose income is more than the people of Indonesia (Herlambang, 2019).

Not only stop there, then APTI Nasional on November 11, 2019 conducted "Empowerment of Ormas" in the framework of handling social problems of the people of Central Java Province in 2019. and in collaboration with DPD APTI Central Java discussed the issue of tobacco farmers, especially in central Java, then on the same day APTI held a National Leadership Meeting attended by representatives of tobacco farmers in 10 provinces in Indonesia which in it discussed the impact of PMK 152/0.10 of 2019 and those present in the discussion were GanjarPranowo, Agency Minister of Customs, and Representative of the Minister of Agriculture (Rizqi, 2021).

\section{Indonesian Tobacco Farmers Association of Temanggung Regency}

To facilitate the politics of resistance, APTI Temanggung Regency in conducting pressure both at the National and local levels that use the patterns, symbols, and beliefs of tobacco farmers invoking the screams of farmers' problems is certainly related to the views of Temanggung regency tobacco farmers against APTI who have been fighting for farmers' rights.

The first was one of the responses from tobacco farmers of LamukLegok Hamlet to the Indonesia Tobacco Farmers Association:

"Ithink APTI is a container from tobacco farmers in Temanggung Regency, so it contributes to farmers, because in APTI itself there are many things that are done, many things are done by APTI as a result. Farmers in the mountains sometimes do not know about season and weather mythology, what APTI does is inform about the weather conditions in the year, for example this year the drought is earlier so it tells tobacco farmers "let's plant early". Second, APTI socialistizes so that the tobacco can grow and produce good quality tobacco. For example, APTI twigs APTIin villages and hamlets recommend using organic fertilizers instead of using chemical fertilizers during tobacco cultivation. Although sometimes during the season farmers often use chemical fertilizers, but we try not to use it excessively, because so far the farmer's view is that if you want satisfactory results then the chemical fertilizer used must also be a lot too, this is the wrong direction. The disadvantage is to damage the nutrients of the land, the second coss farmers will increase if the farmer does not calculate it. Furthermore, regarding the seedlings in the friend there are 6 types, APTI effort also gives input so that the seeds used in accordance with the land that will be worked by the farmer whose results can be more maximal and the second

149| Journal of Local Government Issues (LOGOS), 4 (2), September 2021, pp 136154

ISSN : 2620-8091 print | 2620-3812 online 
seedling will be resistant to disease. Third, reducing the cost of cultivation of APTI production efforts in the Ministry and related agencies so that DBH CHT can return to tobacco farmers, both from the help of seedlings, fertilizers and tools in an effort to reduce the cos production costs of tobacco farmers The fourth is related to existing regulations so far, APTI always voiced the anxiety of farmers and does not always use a lot of time sometimes using representatives of administrators directly to Jakarta, to the Ministry, and even to penetrate to the Palace to secure regulations that harm farmers, because we are in the country of law, but the law must be balanced, where the benefits and impacts must be considered so that the interests of farmers must also be considered" (Interview, 2020).

From the farmer's question APTI Temanggung Regency is a container of farmers' aspirations and presenters of the aspirations of tobacco farmers to the stakeholders in terms of regulations that harm tobacco farmers, not only regarding regulations that harm farmers but APTI also seeks that DBH CHT resulting from tobacco excise can return to farmers and help farmers reduce Coss production costs.

Furthermore, tobacco farmers in LamukLegok Hamlet, Legoksari Village according to his view are;

"In my opinion, APTI Temanggung Regency in protesting government regulations that harm tobacco farmers is very good, and we entrust it to APTI, secondly, APTI also plays a role in tobacco cultivation, namely socializing and with good fertilizer extension, Assistance from DINTAPANGAN in the form of fertilizer is very useful for farmers, (derived from DBH CHT) so as to alleviate the value of farmers' production, but at the time of post-harvest in terms of our sales (farmers) who were bumped in destroy (chaotic) commerce because it is no secret that the tobacco trade in Temanggung was destroyed. "(Interview, 2020).

"Third, regarding the absorption of local tobacco friends are all absorbed in Legoksari but the price is not in accordance with what tobacco farmers expect in Legoksari, because the quota in the manufacturer is full by the (players) who are pumped to the price of the shoot we bring, my own tobacco that should be of such quality in 2014 ranges from 700,000 to 750,000 per Kg but in 2019 is priced at a maximum price of 400,000 this is the price of 400,000. ampak of these tobacco artisans who meet quotas in the manufacturer" (Interview, 2020).

"However, for APTI trading has not played an active role, DINTAPANGAN in my opinion also has not sided with farmers, especially for commercial arrangements. Because APTI in my opinion there is no kind of rule to farmers to fix this chain of commerce, so from the farmers the main thing is to maintain the quality and guarantee of local tobacco, and now tobacco farmers in Legoksari lose to the "family farming business" tobacco. So if APTI does want to defend farmers, by stopping the import of tobacco from outside the family" (Interview, 2020).

"My advice to improve the welfare of tobacco farmers in Temanggung Regency to increase, can be done in two ways, namely the petama, stop outside imports and stop "family farming business" tobacco (must). Imports in Temanggung are many because of these 'family farming businesses' that make it exist. From

150| Journal of Local Government Issues (LOGOS), 4 (2), September 2021, pp 136154

ISSN : 2620-8091 print | 2620-3812 online 
Gudang Garam itself is also very aggrieved by the existence of this "family farming business" because it feels aggrieved, which is expected to form, taste, aroma is tobacco friends but in fact forms like friends but the taste and aroma of east Java taste." (Interview, 2020).

APTI Temanggung Regency in applying pressure to central and regional regulations is very sharp, consistent and often invites tobacco farmers in hearings with the political elite but blunt when it comes to trade trade especially in Temanggung Regency, maybe from this disappointment there are some issues about APTI in the District not the Indonesian Tobacco Farmers Association but APTI is the Indonesian Tobacco Traders Association where there has been no firm step. APTI done in relation to the local capitalist, although the local capitalist has only been felt by tobacco farmers of Temanggung Regency for the past 6 years.

\section{CONCLUSION}

Based on the results of research and discussions that have been outlined in the previous chapter of the Indonesian Tobacco Farmers Association, Temanggung Regency is a forum for tobacco farmers and also started the movement of local-scale tobacco farmers who were able to encourage the birth of Government Regulation Number 19 of 2003. especially article 52 where the Local Government is obliged to establish a NonSmoking Area in its territory with Local Regulations, has not realized PERMENTAN Number 23 of 2019 whose impact is not absorbed local tobacco where in the recommendation of tobacco imports must absorb local tobacco 2 times what will be imported, PMK 222 in 2017 where the use of DBH-CHT is at least 50\% of the allocation of DBH CHT in each region and less than 10\% returned to tobacco farmers, the last of which is PMK 152 in 2019 where the increase in HJE 26\% and excise duty of 17\% in the regulation the impact is that the percentage of local tobacco absorption will be reduced and can even reduce the purchase price of local tobacco. The role of a leader who has an awareness of the injustice caused by pressure and discrimination carried out by the state so as to fight for the rights of tobacco farmers and consistent in maintaining the politics of the community and mobilizing the resources of the Association and Laskar Kretek.

\section{REFERENCES}

Anderson, R. K. (2019). Toward Thick Responsiveness: Engaging Identity-Based Student Protest Movements. The Journal of Higher Education, 90(3), 402-426. https://doi.org/10.1080/00221546.2018.1512803

Asregadoo, T. (2017). “A Bulwark Against Radicalism:" Protest Movements at the University of Pennsylvania and the Struggle for Reform, 1965-1969. Peace \& Change, 42(3), 410-435. https://doi.org/10.1111/pech.12247

Baker, M. (2016). The Prefigurative Politics of Translation in Place-Based Movements of Protest: Subtitling in the Egyptian Revolution. The Translator, 22(1), 1-21. https://doi.org/10.1080/13556509.2016.1148438

Bilewicz, A. M. (2020). Beyond the Modernisation Paradigm: Elements of A Food Sovereignty Discourse in Farmer Protest Movements and Alternative Food

151| Journal of Local Government Issues (LOGOS), 4 (2), September 2021, pp 136154

ISSN : 2620-8091 print | 2620-3812 online 
Networks in Poland. Sociologia Ruralis, 60(4), 754-772. http://dx.doi.org/10.1111/soru.12295

Bonde, D. (2019). PESektor Pertanian Yang Mempengaruhi Perekonomian Daerah Dalam Pelaksanaan Otonomi Daerah Di Kab. Bolaang Mongondow Utara. https://www.researchgate.net/publication/330037147_Sektor_Pertanian_Yang_ Mempengaruhi_Perekonomin_Daerah_Dalam_Pelaksanaan_Otonomi_Daerah_Di_ Kab_Bolaang_Mongondow_Utara.

Cima, E. (2015). Dinamika Protes dan Perlawanan Masyarakat dalam Pembangunan Irigasi Mbay Kiri di Kelurahan Mbay II Kecamatan Aesesa Kabupaten Nagekeo NTT. Tesis: Universitas Gadjah Mada Yogyakarta.

Coretti, L., \& Pica, D. (2015). The Rise and Fall of Collective Identity in Networked Movements: Communication Protocols, Facebook, and the Anti-Berlusconi Protest. Information, Communication \& Society, 18(8), 951-967. https://doi.org/10.1080/1369118X.2015.1043317

Creswell, J. W., \& Creswell, J. D. (2017). Research Design: Qualitative, Quantitative, and Mixed Methods Approaches: Sage publications.

Denzin, N. K., \& Lincoln, Y. S. (2011). The Sage Handbook of Qualitative Research. Sage Publications.

Emzir, E. (2013). Metodologi Penelitian Pendidikan: Kuantitatif dan Kualitatif. Jakarta: Rajawali Pers.

Erman, E. (2017). Politik Protes dan Etnisitas: Kasus Buruh Cina di Tambang Timah di Bangka-Belitung (1920-1950). Masyarakat Indonesia, 36(1), 1-28. https://doi.org/10.14203/jmi.v36i1.625

Fernyawan, D. (2021). Analisis Hubungan antar Stakeholder pada Pengeringan Daerah Irigasi Serayu dalam Protes Petani di Kecamatan Kesugihan dengan Social Network Analysis. Journal of Agricultural and Biosystem Engineering Research, 2(1), 34-44. doi:10.20884/1.jaber.2021.2.1.4076

Hardanis, A. N. H., \& Poerwono, D. (2013). Analisis Efisiensi Faktor-Faktor Produksi Usahatani Tembakau Rakyat Kabupaten Temanggung. Diponegoro Journal of Economics, $3(1)$ 14-25. https://ejournal3.undip.ac.id/index.php/jme/article/view/5311

Hartutik, H., \& Sukirno, S. (2018). Gerakan Protes Petani Klaten. SEUNEUBOK LADA: Jurnal ilmu-ilmu Sejarah, Sosial, Budaya dan Kependidikan, 5(1), 95-105.

Hendarto, K. A. (2021). Protes Perajin Tahu-Tempe Dalam Wacana Media: Sebuah Penelitian Awal Menggunakan Analisis Isi. Conference in Business, Accounting and Management (CBAM), 1(2), 485-502.

Herlambang, A. (2019). Naikkan Cukai 22\%, Petani Tembakau Protes Menkeu di Depan Istana. semarang.ayoindonesia https://semarang.ayoindonesia.com/nasional/pr77778683/Naikkan-Cukai-22-Petani-Tembakau-Protes-Menkeu-di-Depan-Istana

Hill, T., Canniford, R., \& Millward, P. (2018). Against Modern football: Mobilising Protest Movements in Social Media. Sociology, 52(4), 688-708. https://doi.org/10.1177\%2F0038038516660040

Hoffman, L., Granger Jr, N., Vallejos, L., \& Moats, M. (2016). An Existential-Humanistic Perspective on Black Lives Matter and Contemporary Protest Movements. 
Journal of humanistic psychology, 56(6), 595-611. https://doi.org/10.1177\%2F0022167816652273

Huda. (2017). Ratusan Petani Tembakau di Jateng Demo Desak RUU Pertembakauan Segera Disahkan. https://jateng.tribunnews.com/2017/01/09/ratusan-petanitembakau-di-jateng-demo-desak-ruu-pertembakauan-segera-disahkan.

Indonesia, P. R. (2007). Peraturan Pemerintah Republik Indonesia Nomor 81 Tahun 1999 tentang Pengamanan Rokok bagi Kesehatan: Pasal.

Indonesia, R. (2009). Undang-undang Republik Indonesia nomor 36 tahun 2009 tentang Kesehatan. Jakarta Republik Indones.

Iryana, W. (2016). Protes Sosial Petani Indramayu Masa Pendudukan Jepang (19421945). Tsaqofah \& Tarikh: Jurnal Kebudayaan dan Sejarah Islam, 1(1), 77-90. http://dx.doi.org/10.29300/ttjksi.v1i1.865

Iryana, W. (2017). Protes Sosial Masyarakat Parean Girang, Indramayu terhadap Relokasi Peternakan Babi (1995-1996). Tsaqofah dan Tarikh: Jurnal Kebudayaan dan Sejarah Islam, 2(1), 61-76. https://doi.org/10.15575/al-tsaqafa.v13i01.1832

Jacobs, K. (2016). Disorderly Conduct: Feminist Nudity in Chinese Protest Movements. Sexualities, 19(7), 819-835. https://doi.org/10.1177\%2F1363460715624456

Jolley, R., \& Steinfeld, J. (2019). Protest Works: Two Activists on How Their Protest Movements Led to Real Political Change in Hungary and Romania. Index on Censorship, 48(4), 69-72. https://doi.org/10.1177\%2F0306422019895468

Juris, J. S. (2015). Embodying Protest: Culture and Performance Within social movements. Anthropology, theatre, and development (pp. 82-104): Springer. https://doi.org/10.1057/9781137385796_11

Kasanti, A. I., \& Adnan, M. (2019). Cantrang yang Dilarang: Potret Dinamika Protes Nelayan Juwana. Journal of Politic and Government Studies, 8(03), 81-90.

Keuangan, P. M. (2019). Rincian Dana Bagi Hasil Cukai Daerah Provinsi/Kabupaten. Jakarta: Kementerian Keuangan.

Laouni, N.-E. (2020). Cyberactivism and Protest Movements: the February 20th Movement-the Forming of A New Generation in Morocco. The Journal of North African Studies, 1-30. https://doi.org/10.1080/13629387.2020.1810024

Lejano, R., Chui, E., Lam, T., \& Wong, J. (2018). Collective Action as Narrativity and Praxis: Theory and Application to Hong Kong's Urban Protest Movements. Public Policy and Administration, 33(3), 260-289. https://doi.org/10.1177\%2F0952076717699262

Lochan, V. (2019). Embodied Forms of Politics and Identity in South Asian Protest Movements: Pinjra Tod and Delhi. Asian Journal of Women's Studies, 25(1), 132147. https://doi.org/10.1080/12259276.2019.1577032Maskur, F. (2020). Lahan Tanaman Tembakau Temanggung Susut 4.600 Hektare Tahun Ini. https://ekonomi.bisnis.com/read/20200713/99/1265032/lahan-tanamantembakau-temanggung-susut-4.600-hektare-tahun-ini.

Muhammad, F. P. (2013). Politik Lokal dan Pemerintahan Daerah: Studi Kritis Pemerintahan Ponorogo Tahun 2000-2012. Skripsi : Universitas Darusalam Gontor.

Munck, R. (2015). Paul Almeida (2014), Mobilizing Democracy: Globalization and Citizen Protest. Baltimore: Johns Hopkins University Press. \$29.95, pp. 216, pbk.-

153| Journal of Local Government Issues (LOGOS), 4 (2), September 2021, pp 136154

ISSN : 2620-8091 print | 2620-3812 online 
Cristina Flesher Fominaya (2014), Social Movements and Globalization: How Protests, Occupations and Uprisings are Changing the World. Basingstoke: Palgrave Macmillan.£ 24.99, pp. 248, pbk. Journal of Social Policy, 44(2), 411-412.

Neira, C. C. (2018). Book review: Luisa Martín Rojo (ed.), Occupy: The Spatial Dynamics of Discourse in Global Protest Movements: SAGE Publications Sage UK: London, England. https://doi.org/10.1177\%2F0957926517753793d

Nurwiyati, R. T., \& Herawati, N. R. (2017). Peran Asosiasi Petani Tembakau Indonesia (APTI) dalam Memperjuangkan Kepentingan Petani Tembakau di Kabupaten Temanggung. Journal of Politic and Government Studies, 6(04), 311-320. https://ejournal3.undip.ac.id/index.php/jpgs/article/view/17644.

Peraturan, P. (2012). Peraturan Pemerintah Republik Indonesia Nomor 109 Tahun 2012 tentang Pengamanan Bahan yang Mengandung Zat Adiktif Berupa Produk Tembakau bagi Kesehatan. https://peraturan.bpk.go.id/Home/Details/5324/pp-no-109-tahun-2012

Perkebunan, D. J. Luas Tanam Tembakau Menurut Provinsi Di Indonesia 2015 - 2019.: Direktorat Jendral Perkebunan.

Prasetiyo, A., Djajadi, D., \& Sudarto, S. (2017). Kajian Produktivitas dan Mutu Tembakau Temanggung Berdasarkan Nilai Indeks Erodibilitas dan Kepadatan Tanah. Jurnal Tanah dan Sumberdaya Lahan, 3(2), 389-399.

Ramli, R. (2019). Cukai Rokok Tahun Depan Naik 21,55 Persen, Petani Tembakau Protes.

https://www.antaranews.com/beritaRamli,\%20R.\%20(2019).\%20Cukai\%20Ro kok\%20Tahun\%20Depan\%20Naik\%2021,55\%20Persen,\%20Petani\%20Temba kau\%20Protes.\%20Retrieved\%20from\%20inews.id\%20website:\%20https://w ww.inews.id/finance/makro/cukai-rokok-tahun-depan-naik-2155-persenpetani-tembakau-protes/1533088/lahan-tembakau-di-temanggung-turun2000-hektare-ini-penyebabnya.

Rizqi, A. (2019). Di Magelang, Asosiasi Petani Tembakau Tolak Kenaikan Harga Rokok. https://www.solopos.com/di-magelang-asosiasi-petani-tembakau-tolakkenaikan-harga-rokok-1030360.

Rizqi, A. (2021). Di Magelang, Asosiasi Petani Tembakau Tolak Kenaikan Harga Rokok. https://www.solopos.com/di-magelang-asosiasi-petani-tembakau-tolakkenaikan-harga-rokok-1030360.

Sunaryo, T. (2013). Opini Akademik Atas Peraturan Pemerintah Nomor 109 Tahun 2012 Tentang Pengamanan Bahan yang Mengandung Zat Adiktif Produk Tembakau Bagi Kesehatan. Jakarta: Serikat Kerakyatan.

Suyitno, H. (2020). Lahan tembakau di Temanggung turun 2.000 hektare ini penyebabnya. https://www.antaranews.com/berita/1533088/lahan-tembakaudi-temanggung-turun-2000-hektare-ini-penyebabnya.

Zaini, K. (2014). Dependency Theory: Solusi mengatasi kapitalisme di Indonesia. https://www.academia.edu/32037559/Paper_Dependency_Theory_Solusi_meng atasi_kapitalisme_di_Indonesia 